\title{
Expediency of Flea Tree (Albizia lebbeck $L$.) in the prevention of known human fungal and bacterial strains
}

Khushnood Ur Rehman ${ }^{1 *}$, Muhammad Hamayun ${ }^{2}$, Gulzad Ahmad ${ }^{1}$, Tabassum Yaseen ${ }^{3}$, Zahid Ali Butt ${ }^{4}$, Saqib Ullah ${ }^{1}$, Saleena Khan ${ }^{1}$ and Tauhid Khan ${ }^{1}$

1. Department of Botany, Islamia College, Peshawar-Pakistan

2. Department of Botany, Abdul Wali Khan University, Mardan-Pakistan

3. Department of Botany, Bacha khan University, Charsadda-Pakistan

4. Department of Botany, GC Women University, Sialkot-Pakistan

*Corresponding author's email: drkhushnood@icp.edu.pk

Citation

Khushnood Ur Rehman, Muhammad Hamayun, Gulzad Ahmad, Tabassum Yaseen, Zahid Ali Butt, Saqib Ullah, Saleena Khan and Tauhid Khan. Expediency of Flea Tree (Albizia lebbeck L.) in the prevention of known human fungal and bacterial strains. Pure and Applied Biology. Vol. 10, Issue 4, pp1080-1087.

http://dx.doi.org/10.19045/bspab.2021.100112

\begin{tabular}{llll}
\hline \hline Received: 24/08/2020 & Revised: 29/10/2020 & Accepted: 05/01/2021 & Online First: 12/01/2021 \\
\hline \hline
\end{tabular}

\section{Abstract}

Albizia lebbeck $\mathrm{L}$. is one of the best medicinal plants in the province of Khyber Pakhtunkhwa Pakistan. It possesses different properties but the most important one, it is used in local remedies. The antibacterial and antifungal properties of different fractions were obtained from the selected plant studied. For Antibacterial activity, four strains of bacteria were selected which cause different diseases in humans, these bacteria were Streptococcus mutans, Serratia marcescens, Staphylococcus aureus, and Methicillin resistance staphylococcus aureus. The extract obtained from the Albizia lebbeck $L$. were fractionated into Chloroform, methanolic, $n$-hexane, Ethyl acetate, and Aqueous fractions. The highest antibacterial activity was shown by methanolic extracts (38$48 \%$ ) and the lowest activity by an aqueous fraction (19-36\%). While in antifungal activity the fractions were tested against four fungal species including Polyspndylium pallidum, Aspergillus flavus, Alternaria alternate, and Fusarium oxysporum. The aqueous extract shows the lowest activity with minimum efficacy in comparison to the standard drug (20-30\%), Crude methanolic extract shows a high zone of inhibition followed by $n$-hexane. The study concluded that $A$. lebbeck have significant antimicrobial potential and might be helpful in antibiotics.

Keywords: Antibacterial; Antifungal activity; Antimicrobial; Flea tree; Albizia lebbeck

Introduction

It is globally accepted that the first medicine in human history was the medicinal plants [1]. Different people of a different time with the help of writing or in other ways disclosed the therapeutic properties of medicinal plants [2]. They have many properties in clinics from cough to cancer. From the $18^{\text {th }}$ century, the pharmacologist was busy to find medicinal plants and knowledge about their constituents to use against different diseases. They consist of two types of metabolites i.e. primary and secondary metabolites $[3,4]$. The primary metabolites help in growth and 
development while secondary metabolites run many biochemical pathways and give therapeutic property to plants [5]. The fractions obtained from the selected plant show the therapeutic properties against different pathogens including bacteria and fungi [6]. The medicinal plants were used in different parts of the world but in Asia, it is used about $80 \%$. It is also used in Latin America and Africa with minimal side effects [7]. According to some research such as the World health organization (WHO), in the whole world population, about $80 \%$ used traditional medicine which is prepared from medicinal plants [8]. For millennia it is known that medicinal plants have the potential to fight against microorganisms and people of different countries especially China, India, and the northeast were initially known to prepare drugs from the medicinal plants [9]. But with the passage of time and the failure of therapies these drugs were failed against microbes. After that different precuts were used against them which shows a very significant role against them. Fungi and Bacteria have a dual threatening effect because they not only diseased our economic crops but also causing toxicities and allergies. Fungicides that fight against fungal diseases prepared from medicinal plants [10]. In this regard, the present study was held to find anti-fungal and anti-bacterial activity.

Albizia lebbeck L. is a dioecious plant with compound leaves fruit is flat and oblong and distributed in Australia, Asia, Africa and South America [11]. The seed is round and colorful and usually grown as a wild plant. It also possesses therapeutic properties. The fractions obtained from the plant showed antifungal and antibacterial activity. These different extracts such as methanolic and Ethanolic fractions possess different properties against certain diseases such as anticancer, hypoglycemic, antiprotozoal, and anti-fertility effect $[9,12]$. While on the other hand traditionally it is used against pain, inflammatory, analgesic [13]. The drugs which are prepared from the plants have the potential to use against certain diseases of human beings which are caused by microorganism especially bacteria and fungi [14].

\section{Materials and Methods}

\section{Collection and Processing of the Plant Specimen}

A. lebbeck L. collected from different areas of Peshawar, KP, Pakistan. After collection, the plants were washed with water, dried, in newspapers to absorb moisture from the plants. For further drying, they were placed in the oven for $24 \mathrm{hrs}$ under $40^{\circ} \mathrm{C}$. When the plants were completely dried they were ground by grinder for powder formation. The powder was placed in a dried and cool area for further activities.

\section{Preparation of Extract and Fractionation}

Active metabolites were extracted using the cold maceration method. In two liters' ethanol one and a half kilogram of powdered which was made from the selected plant was dipped and incubated at $25^{\circ} \mathrm{C}$. After that, the filtrate obtained by filtration of mixture thrice using filter paper. For evaporation then it was subjected to a rotary evaporator at $40^{\circ} \mathrm{C}$. Then it is again dried and dissolved in $100 \mathrm{ml}$ of distilled water. For fractionation different organic solvents such as ethanol, methanol, and n-hexane were used. All the fractions thus obtained were concentrated by rotary evaporator and designated as solventextracted fractions [15].

\section{Test Microorganism}

A total of four bacterial and four fungal species were tested. The bacteria species Streptococcus mutans, Serratia marcescens, Staphylococcus aureus, and Methicillin resistance staphylococcus aureus (MRSA) which cause diseases in human beings and the fungal species are Polyspndylium pallidum, Fusarium oxysporum, Alternaria alternate and Aspergillus flavus [15].

Antibacterial bioassay 
Antibacterial activity of crude extracts was carried out in Petri dishes by disc diffusion method [12]. $6 \mathrm{mg} / \mathrm{ml}$ of dilute culture was transferred to the petri dish and placed at $37^{\circ} \mathrm{C}$ for $30 \mathrm{~min}$. After transferring $8 \mathrm{~mm}$ diameter disc was used for soaking of differently concentrated solutions. For positive control, Gentamicin, $20 \mu \mathrm{g}$, and Gatifloxacin $20 \mu \mathrm{g}$ was used while for negative control soaked disc with distilled water is used. The disc was placed in plates and incubated for $24 \mathrm{hr}$ at $37^{\circ} \mathrm{C}$. The inhibition zone was measured after the completion of incubation [15].

\section{Antifungal bioassay}

During antifungal activity four fungal strains Polyspndylium pallidum, Fusarium oxysporum, Alternaria. alternate and Aspergillus flavus were studied. Sabouraud agar medium was used in Petri dishes for such activity. $6 \mathrm{mg} / \mathrm{ml}$ fractions were poured into each plate and the same size disc which was used for antibacterial activity was used. For incubation, such plates were placed for one day at human body temperature $\left(37^{\circ} \mathrm{C}\right)$. When the incubation period was completed inhibition zone was measured [16].

\section{Statistical analysis}

The statistical analysis was done through ANOVA and SPSS data analysis.

\section{Results}

The focused antimicrobial activities of different fractions of $A$. lebbeck $\mathrm{L}$. revealed momentous effects against different bacterial and fungal strains of humans. The biochemical must be followed to isolate substantial compounds for the preparation of antibiotics [17]. For this purpose, antimicrobial activities were carried out.

\section{Antibacterial activity}

In our results the antibacterial properties (Fig. $1 \& 2$ ) of $A$. lebbeck. Crude Methanolic extract inhibited the growth of $S$. aureus $(10.3 \pm 0.65 \mathrm{~mm}$ with $38.47 \%), S$. mutans (12.4 $\pm 0.56 \mathrm{~mm}$ and 43\%), MRSA was restricted $(12.1 \pm 0.89 \mathrm{~mm}$ and $48.5 \%)$, and $S$. marcescens $(09 \pm 0.68 \mathrm{~mm}$ and $42.87 \%)$. The restriction showed by $n$-hexane fraction was S. aureus $(09.3 \pm 0.36 \mathrm{~mm}$ and $31 \%), S$. mutans $(11 \pm 0.79 \mathrm{~mm}$ and $36 \%)$, MRSA $(09 \pm 0.64 \mathrm{~mm}$ and $32.02 \%)$, and $S$. marcescens (11 $\pm 0.93 \mathrm{~mm}$ and $47.63 \%)$. The Chloroform fraction limited bacterial growth $9.4 \pm 0.43 \mathrm{~mm}$ zone and $34.72 \%, 11.0 \pm 0.56$ $\mathrm{mm}$ and $44 \%, 07 \pm 0.44 \mathrm{~mm}$ and $25 \%$ and $09 \pm 0.55 \mathrm{~mm}$ zone and $42.86 \%$ of Staphylococcus aureus, Streptococcus mutans, Methicillin resistance staphylococcus aureus (MRSA) and Serratia marcescens. Ethyl acetate fraction restricted Staphylococcus aureus to $(12 \pm 0.27 \mathrm{~mm}$ and $46.16 \%)$, the MRSA strain to $(07 \pm 0.19 \mathrm{~mm}$ and $28.03 \%$ ). While $S$. mutans was restricted to $(12.5 \pm 0.11 \mathrm{~mm}$ and $43 \%)$, and $S$. marcescens $(11 \pm 0.16 \mathrm{~mm}$ and $48.33 \%)$. Outer limits of zone inhibition of Aqueous fraction were $S$. aureus $(05.5 \pm 0.47 \mathrm{~mm}$ and $19.53 \%)$, MRSA (9.4 $\pm 0.56 \mathrm{~mm}$ and $35.90 \%), S$. mutans (7.90 $\pm 0.69 \mathrm{~mm}$ zone and $29.11 \%)$, and $S$. marcescens $(7.4 \pm 0.78 \mathrm{~mm}$, and $29.38 \%$ ). The statistical analysis of data shows that one factor ANOVA of antibacterial contains the value of $\mathrm{P}=1.94 \mathrm{x}$ $10^{-09}$ which is very much significant.

\section{Antifungal Activity of Albizia lebbeck L.}

The statistical analysis of data shows that one factor ANOVA of antifungal contains the value of $\mathrm{P}=2.71 \times 10^{-10}$ which is very much significant. The trend of results showed that efficacy against selected was more dependent on the kinds of fraction rather than the type of pathogen. In our results, the antifungal properties (Fig. 3) of A. lebbeck L.Crude Methanolic extract inhibited the growth of Alternaria alternate by $56 \pm 0.58 \mathrm{~mm}$ as highest and restricted Polyspndylium pallidum by $40.0 \pm 0.46 \mathrm{~mm}$ as lowest. The restriction showed by $n$-hexane fraction were, Fusarium oxysporum $(52 \pm 0.48 \mathrm{~mm})$, Alternaria alternate $\quad(50 \pm 0.54)$, Polysphndylium pallidum $(47.0 \pm 0.63 \mathrm{~mm})$, and Aspergillus falvus $(35 \pm 0.69 \mathrm{~mm})$ 
correspondingly. The Chloroform fraction limited fungal growth to $60 \pm 0.34 \mathrm{~mm}$, $55 \pm 0.65 \mathrm{~mm}, 50 \pm 0.37 \mathrm{~mm}$, and $45 \pm 0.31 \mathrm{~mm}$ of Alternaria alternate, Fusarium oxysporum, Polyspndylium pallidum, and Aspergillus flavus correspondingly. Ethyl acetate fraction restricted Alternaria alternate, $\quad(55 \pm 0.47 \mathrm{~mm}), \quad$ Fusarium oxysporum to $(45 \pm 0.43 \mathrm{~mm})$, Aspergillus flavus to $(40 \pm 0.71)$, and Polysphndylium pallidum $(30 \pm 0.57 \mathrm{~mm})$. Outer limits of zone inhibition of aqueous fraction were Alternaria alternate to $(20.0 \pm 0.52 \mathrm{~mm})$, followed by Polyspndylium pallidum, (25.0 $\pm 0.64 \mathrm{~mm})$ Fusarium oxysporum $(25.0 \pm 0.53$ $\mathrm{mm})$, and Aspergillus flavus to $(30.0 \pm 0.56$ $\mathrm{mm})$.

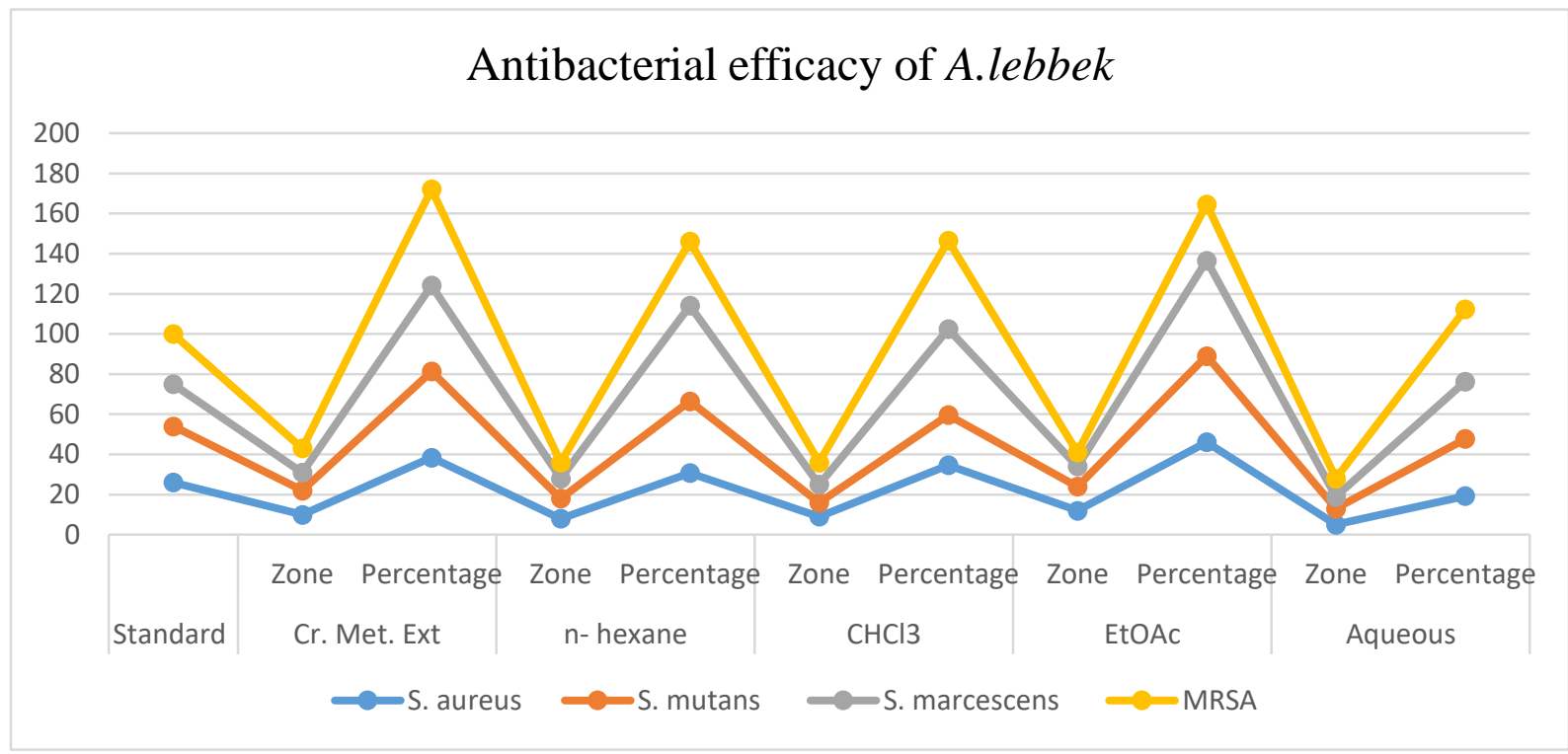

Figure 1. Antibacterial Efficacy and Percentages of Zone of Inhibitions

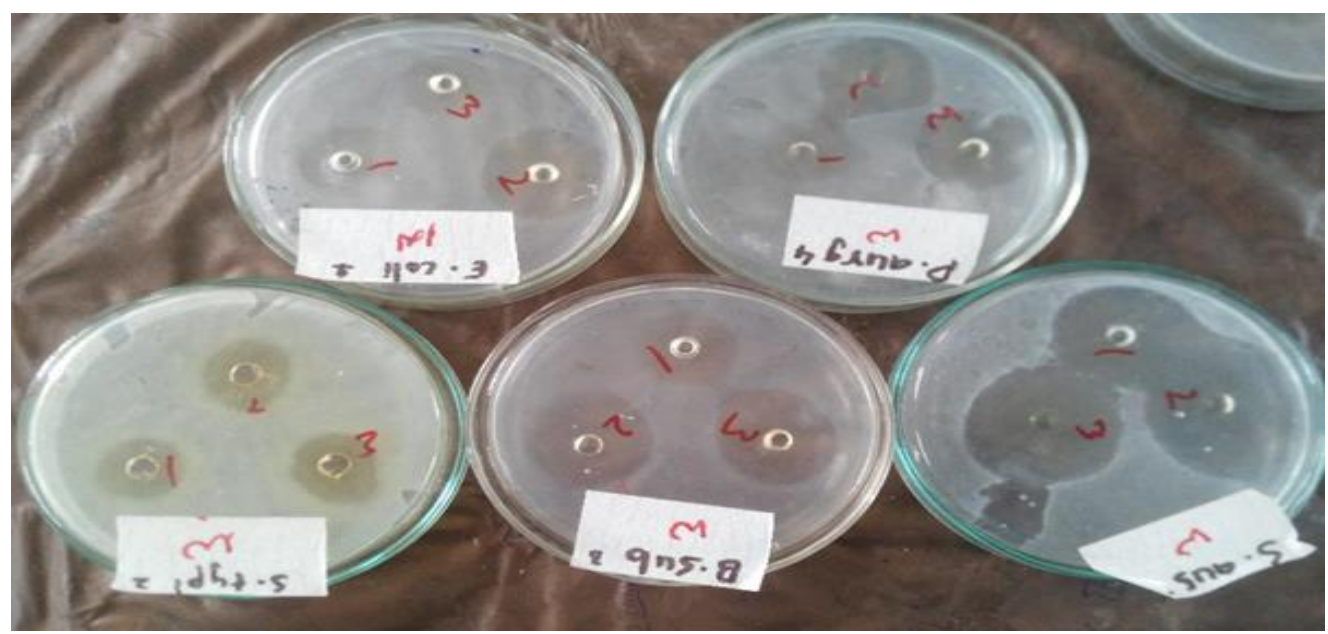

Figure 2. Antibacterial activity of Albizia lebbeck $\mathbf{L}$. 


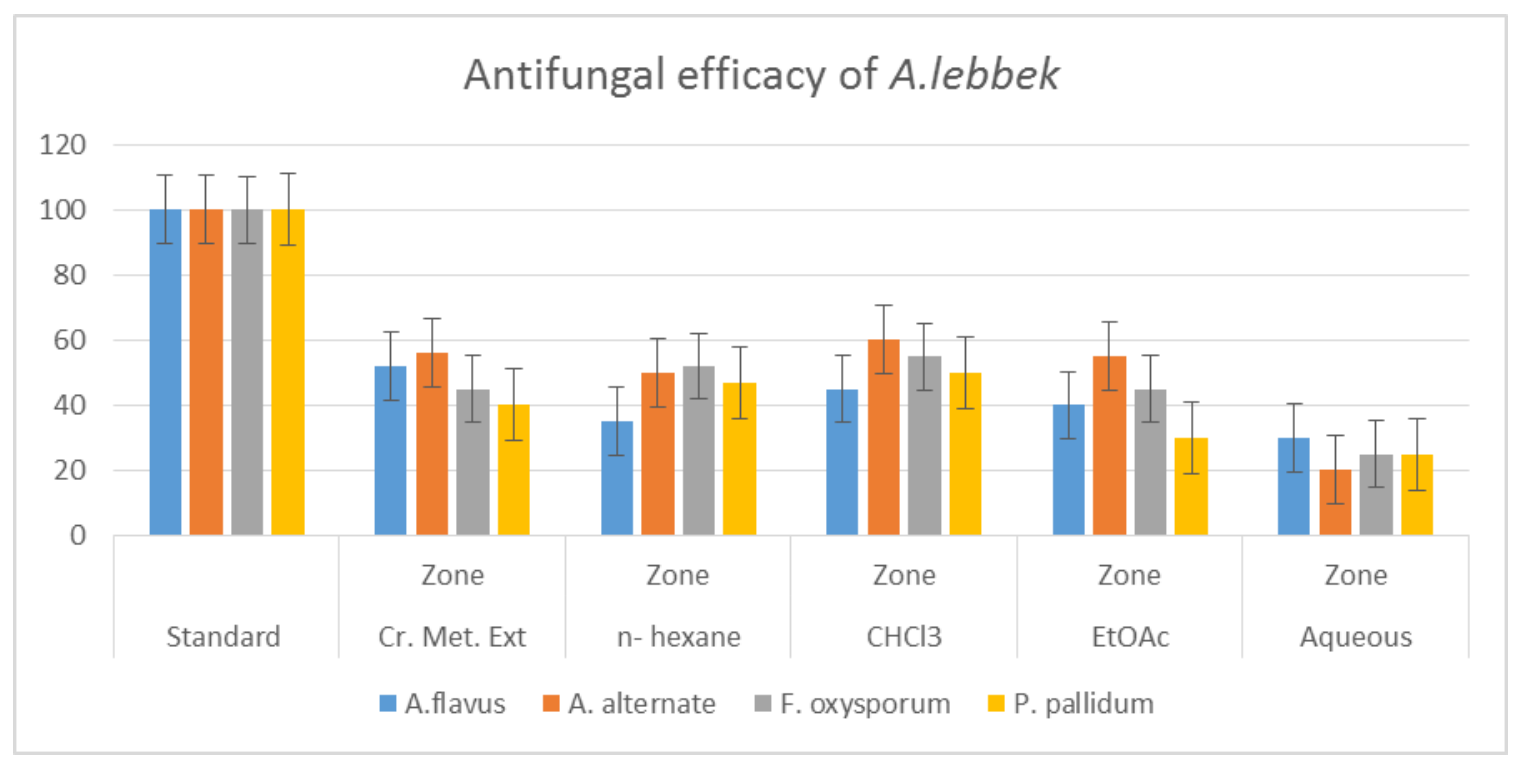

Figure 3. Antifungal Efficacy of Flea tree (Albizia lebbeck L.)

\section{Discussion \\ Antibacterial activity}

The selected bacterial pathogens were Serratia marcescens, Staphylococcus aureus, Methicillin resistance staphylococcus aureus (MRSA), and Streptococcus mutans. A 10 $\mathrm{mg} / \mathrm{ml}$ of the selected medicinal plant fractions were tried out on selected pathogens. The results indicated that all fractions of the selected plant were significantly effective against the selected human pathogens. The statistical analysis of data shows that one factor ANOVA of antibacterial contains the value of $\mathrm{P}=1.94 \mathrm{x}$ $10^{-09} \quad$ (Table 1) which is very much significant. The trend of results showed that efficacy against selected was more dependent on the kinds of fraction rather than the type of pathogen.

\section{Antifungal activity}

The fractionated extracts were tested on common human bacterial and fungal pathogens, which were collected from hospitals. The selected bacterial pathogens were Polyspndylium pallidum, Fusarium oxysporum, Alternaria. alternate and Aspergillus flavus . A $10 \mathrm{mg} / \mathrm{ml}$ of the selected medicinal plant fractions were tried out on selected pathogens. The results indicated that all fractions of the selected plant were significantly effective against the selected human pathogens which are following findings of [18]. The statistical analysis of data shows that one factor ANOVA of antibacterial contains the value of $\mathrm{P}=1.94 \times 10^{-09}$ which is very much significant. The trend of results showed that efficacy against selected was more dependent on the kinds of fraction rather than the type of pathogen $[19,20]$. The statistical analysis of data shows that one factor ANOVA of antifungal contains the value of $\mathrm{P}=2.71 \times 10^{-}$ ${ }^{10}$ (Table 2) which is very much significant [21-23]. The trend of results showed that efficacy against selected was more dependent on the kinds of fraction rather than the type of pathogen [24, 25]. In conclusion, it is very much clear now the plant has a strong antimicrobial potential [26] and has very significant results against bacteria and fungi. 
Table 1. Single-factor ANOVA of Antibacterial efficacy of Flea tree (Albizia lebbeck L.)

\begin{tabular}{|c|c|c|c|c|c|c|}
\hline \multirow{2}{*}{$\begin{array}{c}\text { Summary } \\
\text { Groups }\end{array}$} & \multicolumn{6}{|c|}{ (2) } \\
\hline & Count & Sum & Average & Variance & & \\
\hline Standard & 4 & 100 & 25 & 8.666667 & & \\
\hline Cr. Met. Ext & 4 & 43 & 10.75 & 2.25 & & \\
\hline n- hexane & 4 & 36 & 9 & 1.333333 & & \\
\hline $\mathrm{CHCl} 3$ & 4 & 36 & 9 & 2.666667 & & \\
\hline EtOAc & 4 & 41 & 10.25 & 5.583333 & & \\
\hline Aqueous & 4 & 28 & 7 & 3.333333 & & \\
\hline \multicolumn{7}{|l|}{ ANOVA } \\
\hline Source of Variation & $S S$ & $d f$ & $M S$ & $F$ & $P$-value & F crit \\
\hline Between Groups & 865.8333 & 5 & 173.1667 & 43.59441 & $1.94 \mathrm{E}-09$ & 2.772853 \\
\hline Within Groups & 71.5 & 18 & 3.972222 & & & \\
\hline Total & 937.3333 & 23 & & & & \\
\hline
\end{tabular}

Table 2. Single-factor ANOVA of Antifungal efficacy of Flea tree (Albizia lebbeck L.)

\begin{tabular}{|c|c|c|c|c|c|c|}
\hline \multirow{2}{*}{$\begin{array}{c}\text { Summary } \\
\text { Groups }\end{array}$} & \multirow{2}{*}{ Count } & \multirow{2}{*}{ Sum } & o & 2 & \multicolumn{2}{|l|}{ (2) } \\
\hline & & & Average & Variance & & \\
\hline Standard & 4 & 400 & 100 & 0 & & \\
\hline Cr. Met. Ext & 4 & 193 & 48.25 & 50.91667 & & \\
\hline n- hexane & 4 & 184 & 46 & 58 & & \\
\hline $\mathrm{CHCl} 3$ & 4 & 210 & 52.5 & 41.66667 & & \\
\hline EtOAc & 4 & 170 & 42.5 & 108.3333 & & \\
\hline Aqueous & 4 & 100 & 25 & 16.66667 & & \\
\hline \multicolumn{7}{|l|}{ ANOVA } \\
\hline $\begin{array}{l}\text { Source of } \\
\text { Variation }\end{array}$ & $S S$ & $d f$ & $M S$ & $F$ & $P$-value & F crit \\
\hline $\begin{array}{c}\text { Between } \\
\text { Groups }\end{array}$ & 12690.88 & 5 & 2538.175 & 55.26114 & $2.71 \mathrm{E}-10$ & 2.772853 \\
\hline $\begin{array}{l}\text { Within } \\
\text { Groups }\end{array}$ & 826.75 & 18 & 45.93055556 & & & \\
\hline Total & 13517.63 & 23 & & & & \\
\hline
\end{tabular}

\section{Conclusion}

The present study focused on the antibacterial and antifungal activities that showed significant results through different fractions against different bacterial and fungal strains and might be recommended for molecular and compound level studies.

\section{Author's contribution}

Conceived and designed the experiments: $\mathrm{M}$ Hamayun, Performed the experiments: $M$ Hamayun, $\mathrm{T}$ Yaseen \& KU Rehman,
Analyzed the data: KU Rehman \& S Ullah, Contributed materials/ analysis/ tools: ZA Butt, S Khan \& T Khan, Wrote the paper: KU Rehman, S Ullah \& G Ahmad.

\section{References}

1. Raskin I, Ribnicky DM, Komarnytsky S, Ilic N, Poulev A, Borisjuk N, Brinker A, Moreno DA, Ripoll C \& Yakoby N (2002). Plants and human health in the twenty-first century. TRENDS in Biotechnol 20(12): 522-531. 
2. Macía MJ, García E \& Vidaurre PJ (2005). An ethnobotanical survey of medicinal plants commercialized in the markets of la paz and el alto, bolivia. $J$ of Ethnopharmacol 97(2): 337-350.

3. Croteau R, Kutchan TM \& Lewis NG (2000). Natural products (secondary metabolites). Biochem and Mol Biol of Plants 24(1250-1319.

4. Abubakar MN \& Majinda RR (2016). Gc-ms analysis and preliminary antimicrobial activity of albizia adianthifolia (schumach) and pterocarpus angolensis (dc). Medi 3(1): 1-7.

5. de Dieu Tamokou J, Mpetga DJS, Lunga PK, Tene M, Tane P \& Kuiate JR (2012). Antioxidant and antimicrobial activities of ethyl acetate extract, fractions and compounds from stem bark of albizia adianthifolia (mimosoideae). BMC Complemen and Alter Medi 12(1): 9199.

6. Srinivasan D, Nathan S, Suresh T \& Perumalsamy PL (2001). Antimicrobial activity of certain indian medicinal plants used in folkloric medicine. $J$ of Ethnopharmacol 74(3): 217-220.

7. Seyydnejad SM, Niknejad M, Darabpoor I \& Motamedi H (2010). Antibacterial activity of hydroalcoholic extract of callistemon citrinus and albizia lebbeck. Am J of Appl Sci 7(1): 13-21.

8. Jamshidi-Kia F, Lorigooini Z \& AminiKhoei H (2018). Medicinal plants: Past history and future perspective. $J$ of Herbmed Pharmacol 7(1): 207-220.

9. Vashist H \& Jindal A (2012). Antimicrobial activities of medicinal plants-review. Inte $J$ of Res in Pharma and Biomedi Sci 3(1): 222-230.

10. Shuping D \& Eloff JN (2017). The use of plants to protect plants and food against fungal pathogens: A review. African J of Tradi, Complemen and Alter Medi 14(4): 120-127.
11. Umar H, Kavaz D \& Rizaner N (2019). Biosynthesis of zinc oxide nanoparticles using albizia lebbeck stem bark, and evaluation of its antimicrobial, antioxidant, and cytotoxic activities on human breast cancer cell lines. Inter $J$ of Nanomedi 14(87.

12. Shivanna Y \& Raveesha K (2009). Invitro antibacterial effect of selected medicinal plant extracts. $J$ of Nat Products (India) 2(1): 64-69.

13. Begum HA, Hamayun M, Zaman K, Hussain A \& Ruaf M (2015). Phytochemical evaluation of ethnobotanically selected medicinal plants of mardan, pakistan. $J A d v$ Bot Zool 3(1): 10-21.

14. Lam SK \& Ng TB (2011). First report of an anti-tumor, anti-fungal, anti-yeast and anti-bacterial hemolysin from albizia lebbeck seeds. Phytomedi 18(7): 601608.

15. Slavin YN, Asnis J, Häfeli UO \& Bach $\mathrm{H}$ (2017). Metal nanoparticles: Understanding the mechanisms behind antibacterial activity. $J$ of Nanobiotechnol 15(1): 1-20.

16. Nazzaro F, Fratianni F, Coppola R \& Feo VD (2017). Essential oils and antifungal activity. Pharma 10(4): 86-98.

17. Umar H, Kavaz D \& Rizaner N (2019). Biosynthesis of zinc oxide nanoparticles using albizia lebbeck stem bark, and evaluation of its antimicrobial, antioxidant, and cytotoxic activities on human breast cancer cell lines. Inter J of Nanomedi 14(1): 87-95.

18. Mahmood A, Mahmood A \& Qureshi RA (2012). Antimicrobial activities of three species of family mimosaceae. Pak J of Pharma Sci 25(1): 12-20.

19. Banothu V, Neelagiri C, Adepally U, Lingam J \& Bommareddy K (2017). Phytochemical screening and evaluation of in vitro antioxidant and antimicrobial activities of the indigenous medicinal 
plant albizia odoratissima. Pharma Biol 55(1): 1155-1161.

20. Joycharat N, Thammavong S, Limsuwan S, Homlaead S, Voravuthikunchai SP, Yingyongnarongkul B-e, Dej-adisai S \& Subhadhirasakul S (2013). Antibacterial substances from albizia myriophylla wood against cariogenic streptococcus mutans. Archi of Pharma Res 36(6): 723-730.

21. Ganguli NB \& Bhatt R (1993). Mode of action of active principles from stem bark of albizzia lebbeck benth. Indian $J$ of Experi Biol 31(2): 125-129.

22. Mishra S, Gothecha V \& Sharma A (2010). Albizia lebbeck: A short review. $J$ of Herbal Medi and Toxicol 4(2): 9-15.

23. Samoylenko V, Jacob MR, Khan SI, Zhao J, Tekwani BL, Midiwo JO, Walker LA \& Muhammad I (2009). Antimicrobial, antiparasitic and cytotoxic spermine alkaloids from albizia schimperiana. Nat Prod Commu 4(6): 1123-1134.

24. Kajaria DK, Gangwar M, Kumar D, Sharma AK, Tilak R, Nath G, Tripathi YB, Tripathi J \& Tiwari S (2012). Evaluation of antimicrobial activity and bronchodialator effect of a polyherbal drug-shrishadi. Asian Pacific J of Trop Biomed 2(11): 905-909.

25. Kamanzi Atindehou K, Kone M, Terreaux C, Traore D, Hostettmann K \& Dosso M (2002). Evaluation of the antimicrobial potential of medicinal plants from the ivorycoast. Phyto Res 16(5): 497-502.

26. Verma S, Vashishth E, Singh R, Kumari A, Meena A, Pant P, Bhuyan G \& Padhi M (2013). A review on parts of albizia lebbeck (1.) benth. Used as ayurvedic drugs. Res $J$ of Pharma and Technol 6(11): 1307-1313. 